\title{
Prevalence of symptomatic urinary tract infection and bacterial spectrum of diabetic and non-diabetic patients at the two teaching hospitals in Enugu, Nigeria
}

\author{
${ }^{* 1}$ Okwume, C. C., ${ }^{1}$ Onyemelukwe, N. F., ${ }^{2}$ Abdullahi, I. N., ${ }^{1}$ Okoyeocha, O. E., and ${ }^{1}$ Asamota, S. D. \\ ${ }^{1}$ Department of Medical Laboratory Science, Faculty of Health Science and Technology, University of Nigeria, \\ Enugu Campus, Enugu, Nigeria \\ ${ }^{2}$ Department of Medical Laboratory Science, Faculty of Allied Health Sciences, Ahmadu Bello University, Zaria, Nigeria \\ *Correspondence to: creschidili042@gmail.com and chukwudiokwume97@gmail.com
}

\begin{abstract}
:
Background: Diabetes mellitus is a group of metabolic disorder characterized by relative or absolute lack of insulin. When this condition is not properly managed, it can lead to complications that make diabetic patients vulnerable to urinary tract infections (UTI). The objectives of this study are to determine the prevalence of microbiologically confirmed UTI and the spectrum of uropathogens in diabetic and non-diabetic patients with clinical features of UTI attending the two tertiary hospitals in Enugu State, Nigeria.

Methodology: Clean catch specimen of single mid-stream urine sample was collected from each of 60 ( 22 males, 38 females) diabetic and 60 (22 males, 38 females) non-diabetic patients enrolled using stratified random sampling method. The samples were cultured on standard microbiological culture media (MacConkey and Blood agar plates) and incubated aerobically at $37 \circ \mathrm{C}$ for 24 hours. Plates with significant bacteria growth $\left(>10^{5} \mathrm{CFU} / \mathrm{ml}\right)$ were processed further for bacterial identification using conventional biochemical test scheme. Antibiotic susceptibility test (AST) of each isolate to 17 selected antibiotics was performed by the modified disc diffusion method.

Results: Of the total 120 patients enrolled, 101 had bacterial pathogens isolated from their voided urine samples; 51 of $60(85.0 \%)$ diabetics and 50 of $60(83.3 \%)$ non-diabetics $(p=0.802)$. Bacteria were isolated in $59.1 \%(13 / 22)$ of diabetic and $54.5 \%(12 / 22)$ of non-diabetic male patients compared to $100 \%(38 / 38)$ isolation rate in diabetic and non-diabetic female patients. The most frequently isolated bacteria in the diabetic patients were Proteus spp (18.6\%), Klebsiella spp (16.9\%) and Escherichia coli $(15.5 \%)$ while the most frequently isolated bacteria among the nondiabetic patients were E. coli (30.0\%), Proteus spp (26.3\%) and Enterobacter spp (14.0\%). Apart from Klebsiella spp which was more frequently isolated from the diabetic $(16.9 \%)$ than non-diabetic patients $(6 \%)(p=0.039)$, the frequency other bacterial pathogen isolation such as Proteus spp, E. coli, Enterobacter spp, Pseudomonas aeruginosa, Staphylococcus aureus and Enterococcus spp was not significantly different between the two population groups $(p>0.05)$. The Gram-positive and Gram-negative bacteria were highly sensitive to imipenem in both diabetic and non-diabetic patients, but the isolates from both study groups exhibited low susceptibility to amoxicillin, nitrofurantoin, cefixime and cefuroxime.

Conclusion: Although the overall frequency of bacterial pathogen isolation in the diabetic and non-diabetic patients was not significantly different, females had a higher pathogen isolation rate than the males, and diabetic females had a higher frequency of polymicrobial infections compared to non-diabetic females and the male population. The high antimicrobial resistance of the isolated bacteria pathogens underscores the need for clinical microbiology laboratory testings to optimize the management of UTI in diabetic patients.
\end{abstract}

Keywords: UTI; Diabetes mellitus; Antibiogram; Significant bacteriuria; Pathogen; Enugu 


\title{
Prévalence des infections urinaires symptomatiques et spectre bactérien des patients diabétiques et non diabétiques dans les deux hôpitaux universitaires d'Enugu, au Nigeria
}

\author{
${ }^{* 1}$ Okwume, C. C., ${ }^{1}$ Onyemelukwe, N. F., ${ }^{2}$ Abdullahi, I. N., ${ }^{1}$ Okoyeocha, O. E., et ${ }^{1}$ Asamota, S. D. \\ ${ }^{1}$ Département des sciences de laboratoire médical, Faculté des sciences et technologies de la santé, Université du \\ Nigéria, Campus d'Enugu, Enugu, Nigéria \\ ${ }^{2}$ Département des sciences de laboratoire médical, Faculté des sciences connexes de la santé, Université Ahmadu \\ Bello, Zaria, Nigéria \\ *Correspondance à: creschidili042@gmail.com et chukwudiokwume97@gmail.com
}

\begin{abstract}
Abstrait:
Contexte: Le diabète sucré est un groupe de troubles métaboliques caractérisés par un manque relatif ou absolu d'insuline. Lorsque cette condition n'est pas correctement gérée, elle peut entraîner des complications qui rendent les patients diabétiques vulnérables aux infections des voies urinaires (UTI). Les objectifs de cette étude sont de déterminer la prévalence des infections urinaires confirmées microbiologiquement et le spectre des uropathogènes chez les patients diabétiques et non diabétiques présentant des caractéristiques cliniques des infections urinaires fréquentant les deux hôpitaux tertiaires de l'État d'Enugu, au Nigeria.

Méthodologie: Un échantillon de capture propre d'un seul échantillon d'urine à mi-jet a été prélevé sur chacun des 60 (22 hommes, 38 femmes) patients diabétiques et 60 (22 hommes, 38 femmes) patients non diabétiques inscrits à l'aide d'une méthode d'échantillonnage aléatoire stratifié. Les échantillons ont été cultivés sur des milieux de culture microbiologiques standard (plaques de gélose MacConkey et Blood) et incubés en aérobie à $37^{\circ} \mathrm{C}$ pendant 24 heures. Les plaques avec une croissance bactérienne significative $\left(>10^{5} \mathrm{CFU} / \mathrm{ml}\right)$ ont été traitées davantage pour l'identification bactérienne en utilisant un schéma de test biochimique conventionnel. Le test de sensibilité aux antibiotiques (AST) de chaque isolat à 17 antibiotiques sélectionnés a été réalisé par la méthode de diffusion sur disque modifiée.

Résultats: Sur un total de 120 patients recrutés, 101 avaient des agents pathogènes bactériens isolés de leurs échantillons d'urine évacués; 51 des $60(85,0 \%)$ diabétiques et 50 des $60(83,3 \%)$ des non-diabétiques $(p=0,802)$. Les bactéries ont été isolées chez $59,1 \%(13 / 22)$ des patients diabétiques et $54,5 \%(12 / 22)$ des hommes non diabétiques contre un taux d'isolement de $100 \%(38 / 38)$ chez les femmes diabétiques et non diabétiques. Les bactéries les plus fréquemment isolées chez les patients diabétiques étaient Proteus spp (18,6\%), Klebsiella spp $(16,9 \%)$ et Escherichia coli $(15,5 \%)$ tandis que les bactéries les plus fréquemment isolées chez les patients non diabétiques étaient $E$. coli $(30,0 \%)$, Proteus spp $(26,3 \%)$ et Enterobacter spp $(14,0 \%)$. Hormis Klebsiella spp qui était plus fréquemment isolé chez les diabétiques $(16,9 \%)$ que les patients non diabétiques $(6 \%)(p=0,039)$, la fréquence d'isolement d'autres agents pathogènes bactériens tels que Proteus spp, E. coli, Enterobacter spp, Pseudomonas aeruginosa, Staphylococcus aureus et Enterococcus spp n'étaient pas significativement différents entre les deux groupes de population $(p>0,05)$. Les bactéries Gram-positives et Gram-négatives étaient très sensibles à l'imipénème chez les patients diabétiques et non diabétiques, mais les isolats des deux groupes d'étude présentaient une faible sensibilité à l'amoxicilline, à la nitrofurantoïne, au céfixime et à la céfuroxime.

Conclusion: Bien que la fréquence globale d'isolement des agents pathogènes bactériens chez les patients diabétiques et non diabétiques n'était pas significativement différente, les femmes avaient un taux d'isolement des agents pathogènes plus élevé que les hommes, et les femmes diabétiques avaient une fréquence plus élevée d'infections polymicrobiennes par rapport aux femmes non diabétiques. et la population masculine. La haute résistance antimicrobienne des bactéries pathogènes isolées souligne la nécessité de tests de laboratoire de microbiologie clinique pour optimiser la gestion des infections urinaires chez les patients diabétiques.
\end{abstract}

Mots-clés: UTI; diabète sucré; Antibiogramme; Bactériurie importante; Agent pathogène; Enugu

\section{Introduction:}

Simple urinary tract infection (UTI) is inflammation of the urinary system usually manifesting with frequency, urgency, dysuria, or suprapubic pain in affected patients while complicated UTI occurs in the setting of functional or structural abnormalities of the urinary tracts. Quantitative criterium for establishing a UTI is significant bacteriuria of at least 100,000 colony forming unit (CFU) per $\mathrm{ml}$ of urine in a voided midstream clean catch specimen (1).

Evidence has shown that the incidence of UTI in diabetic patients is four times higher than in non-diabetic patients (2). It has also been reported that the occurrence of UTI in diabetic patients is higher in people with low socioeconomic status and the resistant patterns of microorganisms isolated in diabetic patients differs from those from non-diabetic patients 
(3). Regrettably, treatment of UTI in patients with diabetes is usually associated with worse outcome compared to those without diabetes, seemingly because diabetics seem to have greater difficulty in handling infection once they occur $(4,5)$. Indeed, several aspects of immune system are altered in diabetic patients; polymorphonuclear leukocyte function is compromised particularly when acidosis is present, and adherence, chemotaxis, phagocytosis and bactericidal activity of the leukocytes may also be depressed (6).

UTI is a serious health challenge affecting millions of people each year. In the United States of America, it is estimated from surveys of office practices, hospital-based clinics and emergency departments that there are over eight million cases of UTI annually (7). Many studies have reported incidence of UTI among patients with diabetes mellitus, for example, an observational study of all patients within the United Kingdom general practice research database reported incidence rate of UTI of 46.9 per 1000 persons among diabetic patients versus 29.9 per persons for patients without diabetes (8). An American database study during 2014 (9) found that a UTI diagnosis was more common in subjects with diabetes compared to those without diabetes $(9.4 \%$ vs $5.7 \%)$. Another study in USA with over 70000 patients with diabetes type 2 reported $8.2 \%$ with diagnosis of UTI in one year (10). A Canadian study reported that diabetic females were 6-15 times more frequently hospitalized for acute pyelonephritis than non-diabetic females, and diabetic males were hospitalized 3.4-17 times more than nondiabetic males (11). In a study conducted in Europe, bacteriuria was more prevalent among women with diabetes $(26 \%)$ than in women without diabetes (6\%) (12).

In Nigeria, the prevalence of UTI tend to vary depending on the study population and risk factors. For instance, a prevalence of $61.0 \%$ was reported among pregnant women (13) while a prevalence of $46 \%$ was reported in diabetic patients in Abakaliki (14). Among HIVinfected children and adolescents, a prevalence rate of $32.5 \%$ was reported (15) while $43.6 \%$ rate was reported in the general population without reported risks for UTI (16). In the present study, we determined the prevalence of symptomatic UTI and spectrum of uropathogens among 60 diabetic and 60 non-diabetic patients attending the two tertiary hospitals in Enugu State, Nigeria.

\section{Materials and method:}

\section{Study area}

The study was conducted in the two teaching hospitals in Enugu; University of Nigeria Teaching Hospital (UNTH) and Enugu State University Teaching Hospital (ESUTH), Parklane, Enugu State, Nigeria. The study participants were from out-patient clinics and in-patient general wards of these two hospitals.

\section{Study design and study population}

This was a cross-sectional comparative study of the study population that included diabetic and non-diabetic patients with clinical symptoms and signs of UTI attending the outpatient clinics or hospitalized in the general wards of the two hospitals.

\section{Ethical approval}

Ethical approval was obtained from the Health Research Ethics committee of the University of Nigeria Teaching Hospital Enugu (UNTH/CSA/329/OL.5).

\section{Subject participants and sampling method}

A total of 120 participants with symptoms and signs suggestive of UTI were enrolled into the study, including 60 diabetic (22 males and 38 females), and 60 non-diabetic patients (22 males and 38 females) using stratified random sampling technique. Pooled subjects were divided into groups with similar attributes. Then, simple random sample was taken from each group to ensure that different segments in the population were equally represented. Inclusion criteria were patients of all gender and age groups with symptoms and signs suggestive of UTI, history of diabetes (for the diabetics), and no history of diabetes (for the non-diabetics). Exclusion criteria included pregnancy, history of other underlying illness like HIV/AIDS, and antibiotic usage within 14 days preceding the enrolment

Diabetic patients were enrolled into the study during their regular visits at the endocrinology units of the hospitals through the assistance of their physicians and nurses, while non-diabetics were apparently healthy individuals who were on visit for diabetic status check and confirmed by glucometer measurement of fasting blood glucose (FBS) $\leq 126 \mathrm{mg} / \mathrm{dl}$.

\section{Collection of urine samples}

Urine samples (about $10 \mathrm{ml}$ ) were collected from the study participant who were first 
educated on how to collect a 'clean-catch' midstream urine specimen and the importance of avoiding contamination. They were advised on proper hand washing prior to collection and separation of labia (in females). Urine samples were collected into sterile containers with boric acid preservative and transported to the laboatory within 2 hours.

Urine microscopy, culture and bacteria isolation Each urine sample was cultured on MacConkey agar and Blood agar plates which had been prepared according to manufacturer's instructions. The urine was properly mixed by rotating the container. An inoculating wire loop of $3 \mathrm{~mm}$ diameter was used to inoculate a loopful $(\sim 10 \mu \mathrm{l})$ of the urine sample onto freshly prepared agar and the plates were incubated aerobically at $37^{\circ} \mathrm{C}$ for 24 hours (17). The dip stick test on each urine sample was performed using Combi-10 urine test strips to determine urinary nitrite level and protein/glucose as adjunctive in detecting UTI and screening for diabetic nephropathy, respectively. Wet preparation of centrifuged urine was also examined using the 40x objective lens to detect blood, white blood cells (WBC), epithelial cell, casts, and other cells in the voided urine.

\section{Identification of bacterial isolates}

Culture plates were examined after 24 hours incubation for colony appearance, size, colour, pigmentation, haemolysis, consistency (mucoid, rough, stringy etc), odor, and evidence of lactose fermentation on MacConkey agar. Only plates with significant bacteriuria (> $10^{5} \mathrm{CFU} / \mathrm{ml}$ or $>1000$ colonies) were processed for bacterial identification. Isolates were identified by their Gram stain reactions and by conventional biochemical tests which included catalase and coagulase tests for Gram-positive bacteria, and oxidases, indole, methyl red, Voges Proskauer, urease, litmus milk decolorization, Kligler iron agar (KIA) and citrate utilization tests for Gram-negative bacteria as previously described (17).

\section{Antibiotic susceptibility testing}

Antibiotic susceptibility testing for each isolate was carried out by the Kirby Bauer disc diffusion technique using the Clinical and Laboratory Standards Institute (CLSI) guideline (18). A total of 17 antibiotic discs (HiMedia, Mumbai, India) were employed, which included; ciprofloxacin $(10 \mu \mathrm{g})$, cefuroxime $(10 \mu \mathrm{g})$, amoxicillin $(30 \mu \mathrm{g})$, chloramphenicol $(10 \mu \mathrm{g})$, ofloxacin $(10 \mu \mathrm{g})$, gentamicin $(10 \mu \mathrm{g})$, erythromycin
$(10 \mu \mathrm{g})$, ceftriaxone $(30 \mu \mathrm{g})$, streptomycin (30 $\mu \mathrm{g})$, nitrofurantoin $(100 \mu \mathrm{g})$, levofloxacin $(5 \mu \mathrm{g})$, norfloxacin $(10 \mu \mathrm{g})$, cefixime $(5 \mu \mathrm{g})$, ampicillin/ cloxacillin $(30 \mu \mathrm{g})$, imipenem $(10 \mu \mathrm{g})$, clindamycin $(10 \mu \mathrm{g})$, and pefloxacin $(10 \mu \mathrm{g})$. A suspension of pure colonies of isolated bacteria were inoculated into $0.9 \%$ saline solution and standardized by comparing with 0.5 MacFarland turbidity standard. The surface of sterile Mueller Hinton (MH) agar plate was inoculated using sterile cotton swab soaked in bacterial suspension. Antibiotic discs were placed on inoculated agar plates using sterile forcep, and the plates incubated aerobically at $37^{\circ} \mathrm{C}$ for 24 hours. The diameter of zones of inhibition to each antibiotic disc was measured using a calibrated meter rule and results interpreted as sensitive or resistant according to CLSI guideline (18).

\section{Data analysis}

Data were analysed using the Statistical Package for the Social Sciences (SPSS) version 23.0 window-based program. Two tail Chi-square test was used to determine association between two categorical variables and $p<$ 0.05 was regarded as significant at $95 \%$ confidence interval.

\section{Results:}

A total of 120 patients; 60 diabetics (22 males, 38 females) and 60 non-diabetics (22 males, 38 females) with clinical symptoms and signs of UTI were studied. Of the 120 patients, 101 had bacterial pathogens isolated from their voided urine samples; 51 of 60 $(85.0 \%)$ diabetics and 50 of $60(83.3 \%)$ nondiabetics. The frequency of bacterial pathogen isolation (microbiologically documented UTI) was not significantly different between the two groups $(p=0.802)$ (Table 1$)$.

The most frequently isolated pathogens in the diabetic patients were Proteus spp (18.6\%), Klebsiella spp (16.9\%) and Escherichia coli $(15.5 \%)$ while the most frequently isolated pathogens among the non-diabetic patients were E. coli $(30.0 \%)$, Proteus spp (26.3\%) and Enterobacter spp (14.0\%). Apart from Klebsiella spp which was significantly more frequently isolated from the diabetic $(16.9 \%)$ than non-diabetic patients (6\%) $(p=0.039)$, the frequency of isolation of other bacterial pathogens such as Proteus spp, E. coli, Enterobacter spp, Pseudomonas aeruginosa, Staphylococcus aureus and Enterococcus spp 
was not significantly different between the two population groups $(p>0.05)$. However, Salmonella spp, Citrobacter spp and Providencia spp were exclusively isolated from diabetic patients while Corynebacterium spp was the only pathogen exclusively isolated from one non-diabetic patient.

As shown in Table 2, bacterial pathogens were isolated in only $59.1 \%(13 / 22)$ of diabetic and $54.5 \%(12 / 22)$ of non-diabetic male patients compared to $100 \%$ (38/38) isolation rate in the diabetic and non-diabetic female patients. A total of 46 bacterial pathogens were isolated from the 38 diabetic females indicating polymicrobial infections in some of them while there was only one pathogen (monomicrobial infection) isolated from the non-diabetic female patients and from both the male diabetic and non-diabetic patients.

Tables $3 a$ and $3 b$ showed the percentage sensitivity of the bacterial isolates from diabetic and non-diabetic patients to selected antibiotics. The Gram-positive and Gram-negative bacteria were highly sensitive to imipenem in both diabetic and non-diabetic patients, but the isolates from both study groups exhibited low susceptibility to amoxicillin, nitrofurantoin, cefixime and cefuroxime.

Table 1: Frequency distribution of bacterial isolates from diabetic and non-diabetic patients with urinary tract infections in the two teaching hospitals in Enugu, Nigeria

\begin{tabular}{|c|c|c|c|c|}
\hline Bacterial Isolates & $\begin{array}{c}\text { Diabetics } \\
\text { n (\%) }\end{array}$ & $\begin{array}{c}\text { Non-diabetics } \\
\text { n (\%) }\end{array}$ & $\begin{array}{l}\text { Total } \\
\text { n (\%) }\end{array}$ & $p$ value \\
\hline Proteus spp & $11(18.6)$ & $13(26.3)$ & $24(22.0)$ & 0.332 \\
\hline Klebsiella spp & $10(16.9)$ & $3(6.0)$ & $13(11.9)$ & $0.039 *$ \\
\hline Escherichia coli & $9(15.3)$ & $15(30.0)$ & $24(22.0)$ & 0.171 \\
\hline Pseudomonas aeruginosa & $7(11.9)$ & $3(6.0)$ & $10(9.2)$ & 0.186 \\
\hline Salmonella spp & $6(10.2)$ & 0 & $6(5.5)$ & NA \\
\hline Enterobacter spp & $2(3.4)$ & $7(14.0)$ & $9(8.3)$ & 0.083 \\
\hline Citrobacter spp & $1(1.7)$ & 0 & $1(0.9)$ & NA \\
\hline Providencia spp & $1(1.7)$ & 0 & $1(0.9)$ & NA \\
\hline Staphylococcus aureus & $6(10.2)$ & $5(10.0)$ & $11(10.1)$ & 0.751 \\
\hline Enterococcus spp & $6(10.2)$ & $3(6.0)$ & $9(8.3)$ & 0.298 \\
\hline Corynebacterium spp & 0 & $1(2.0)$ & $1(0.9)$ & NA \\
\hline Total no of isolates & 59 & 50 & 109 & \\
\hline No of patients with isolates & $51(85.0)$ & $50(83.3)$ & $101(84.2)$ & 0.802 \\
\hline $\begin{array}{l}\text { No of patients without } \\
\text { isolates }\end{array}$ & $9(15.0)$ & $10(16.7)$ & $19(15.8)$ & \\
\hline Total no of patients & $60(100)$ & $60(100)$ & 120 & \\
\hline
\end{tabular}


Table 2: Gender distribution of bacterial isolates from diabetic and non-diabetic patients with urinary tract infection in the two teaching hospitals in Enugu, Nigeria

\begin{tabular}{|c|c|c|c|c|c|c|c|c|}
\hline \multirow[t]{2}{*}{ Bacterial isolates } & \multicolumn{4}{|c|}{ Diabetics (n \%) } & \multicolumn{4}{|c|}{ Non-diabetics (n \%) } \\
\hline & Males & Females & Total & $p$ value & Males & Females & Total & $p$ value \\
\hline Proteus spp & $2(15.4)$ & $9(19.2)$ & $11(18.6)$ & 0.756 & $4(33.3)$ & $9(18.8)$ & $13(26.3)$ & 0.272 \\
\hline Klebsiella spp & $1(7.7)$ & $9(19.2)$ & $10(16.9)$ & 0.326 & 0 & $3(6.3)$ & $3(6.0)$ & NA \\
\hline Escherichia coli & $1(7.7)$ & $8(17.0)$ & $9(15.3)$ & 0.376 & $3(25)$ & $12(25.0)$ & $15(30.0)$ & 0.100 \\
\hline Pseudomonas aeruginosa & $2(15.4)$ & $5(10.6)$ & $7(11.9)$ & 0.637 & $1(8.3)$ & $2(4.2)$ & $3(6.0)$ & 0.553 \\
\hline Salmonella spp & $1(7.7)$ & $5(10.6)$ & $6(10.2)$ & 0.754 & 0 & 0 & 0 & NA \\
\hline Enterobacter spp & $1(7.7)$ & $1(2.1)$ & $2(3.4)$ & 0.322 & $1(8.3)$ & $6(12.5)$ & $7(14.0)$ & 0.687 \\
\hline Providencia spp & 0 & $1(2.1)$ & $1(1.7)$ & NA & 0 & 0 & 0 & NA \\
\hline Staphylococcus aureus & $3(23.1)$ & $3(6.4)$ & $6(10.2)$ & 0.075 & $2(16.7)$ & $3(6.3)$ & $5(10.0)$ & 0.242 \\
\hline Enterococcus spp & $2(15.4)$ & $4(8.5)$ & $6(10.2)$ & 0.464 & $1(8.3)$ & $2(4.2)$ & $3(6.0)$ & 0.553 \\
\hline Corynebacterium spp & 0 & 0 & 0 & NA & 0 & $1(2.1)$ & $1(2.0)$ & NA \\
\hline Total no of isolates & 13 & 46 & 59 & & 12 & 38 & 50 & \\
\hline $\begin{array}{l}\text { No of patients with } \\
\text { isolates }\end{array}$ & $13(59.1)$ & $38(100)$ & $51(85)$ & & $12(54.5)$ & $38(100)$ & $50(83.3)$ & \\
\hline $\begin{array}{l}\text { No of patients negative } \\
\text { for isolates }\end{array}$ & $9(40.9)$ & 0 & 9 & & $10(45.5)$ & 0 & 10 & \\
\hline
\end{tabular}

\section{Discussion:}

The overall prevalence rate of microbiologically confirmed bacterial UTI in this study was not significantly different $(p=0.802)$ among diabetic $(85 \%, 51 / 60)$ and non-diabetic patients $(83.3 \%, 50 / 60)$. This disagrees with the study of Saleem and Daniel (2) in Bangalore, India which reported that diabetic patients $(56.4 \%)$ were significantly at increased risk of UTI than non-diabetics (43.6\%). However, diabetic patients in our study who had microbiologically confirmed UTI had more bacterial pathogens isolated from their urine (51 patients had 59 pathogens) compared to the nondiabetic patients (50 patients had 50 pathogens), implying that some of the diabetic patients had polymicrobial infections, a situation that frequently occurs in the elderly, immune compromised, and those with indwelling catheters, HIV, malignancies and diabetes (19), the frequency of which may be as high as $39 \%$ in UTI (20).

The female patients in our study (both diabetic and non-diabetic) had $100 \%$ pathogen isolate rate from their urine samples with some of the female diabetics having polymicrobial infections (38 females with 46 isolated pathogens) while all the female non-diabetics had monomicrobial infection (38 females with 38 isolated pathogens). Comparatively, the diabetic males had $59.1 \%$ (13 of 22 ) pathogen isolation rate while the non-diabetic males had $54.5 \%$ (12 of 22 ) isolation rate.

The anatomical structure of the female urogenital system, with shorter urethra and the close proximity to the anorectal region, may partly contribute to the higher pathogen isolation rates from the female patients as previously established (21). However, the study by Otajevwo (22) in an outpatient setting in Benin City, Nigeria, reported a significantly 
higher prevalence rate of UTI in males $(58.3 \%)$ than females $(41.7 \%)$, which is contrary to the finding of our current study and those of many others.

Table 3a: Percentage sensitivity of bacterial isolates from diabetic patients to selected antibiotics

\begin{tabular}{|c|c|c|c|c|c|c|c|c|c|c|c|c|}
\hline \multirow{2}{*}{$\begin{array}{l}\text { Bacterial isolates } \\
\text { Gram negative bacteria }\end{array}$} & \multirow[t]{2}{*}{ No } & \multicolumn{11}{|c|}{ Percentage ( $\%)$ of isolates sensitive to antibiotics } \\
\hline & & $\mathbf{N}$ & $\mathbf{G N}$ & CIP & $\mathbf{C}$ & OF & $\mathbf{C F}$ & PF & $\mathbf{C T}$ & AMX & ST & IMP \\
\hline Proteus spp & 11 & 9.1 & 63.6 & 63.6 & 18.2 & 45.5 & 9.1 & 36.4 & 36.4 & 27.3 & 45.5 & 90.9 \\
\hline Klebsiella spp & 10 & 0 & 30.0 & 20.0 & 20.0 & 20.0 & 0 & 50.0 & 30.0 & 0 & 0 & 90.0 \\
\hline Escherichia coli & 9 & 33.3 & 66.7 & 44.4 & 33.3 & 44.4 & 22.2 & 44.4 & 44.4 & 22.2 & 44.4 & 88.9 \\
\hline Pseudomonas aeruginosa & 7 & 42.9 & 57.1 & 42.9 & 28.6 & 42.9 & 28.6 & 42.9 & 71.4 & 42.9 & 42.9 & 71.4 \\
\hline Salmonella spp & 6 & 33.3 & 83.3 & 50.0 & 50.0 & 50.0 & 50.0 & 50.0 & 66.7 & 50.0 & 50.0 & 50.0 \\
\hline Enterobacter spp & 2 & 50.0 & 50.0 & 100.0 & 50.0 & 50.0 & 50.0 & 50.0 & 100.0 & 50.0 & 50.0 & 100.0 \\
\hline Citrobacter spp & 1 & 0 & 100.0 & 100.0 & 0 & 100.0 & 0 & 100.0 & 100.0 & 100.0 & 100.0 & 100.0 \\
\hline Providencia spp & 1 & 100.0 & 100.0 & 100.0 & 0 & 100.0 & 0 & 100.0 & 100.0 & 100.0 & 100.0 & 100.0 \\
\hline Gram positive bacteria & & NB & CIP & $\mathbf{G N}$ & OF & CD & $\mathbf{E}$ & CT & AMP & CE & $\mathbf{L V}$ & IMP \\
\hline Staphylococcus aureus & 6 & 0 & 33.3 & 66.7 & 33.3 & 83.3 & 50.0 & 50.0 & 33.3 & 0 & 66.7 & 100.0 \\
\hline Enterococcus spp & 6 & 50.0 & 83.3 & 100.0 & 83.3 & 83.3 & 66.7 & 50.0 & 33.3 & 33.3 & 100.0 & 100.0 \\
\hline
\end{tabular}

Table 3b: Percentage sensitivity of bacterial isolates from non-diabetic patients to selected antibiotics

\begin{tabular}{|c|c|c|c|c|c|c|c|c|c|c|c|c|}
\hline \multirow{2}{*}{$\begin{array}{l}\text { Bacterial isolates } \\
\text { Gram negative bacteria }\end{array}$} & \multirow[t]{2}{*}{ No } & \multicolumn{11}{|c|}{ Percentage (\%) of isolates sensitive to antibiotics } \\
\hline & & $\mathbf{N}$ & GN & CIP & $\mathbf{C}$ & OF & CF & PF & CT & $\mathbf{A X}$ & ST & IMP \\
\hline Proteus spp & 13 & 53.9 & 30.8 & 30.8 & 15.4 & 30.8 & 0 & 23.1 & 61.5 & 7.7 & 30.8 & 100.0 \\
\hline Klebsiella spp & 3 & 66.7 & 100.0 & 100.0 & 66.7 & 100.0 & 33.3 & 100.0 & 100.0 & 33.3 & 66.7 & 100.0 \\
\hline Escherichia coli & 15 & 66.7 & 40.0 & 33.3 & 20.0 & 20.0 & 0 & 20.0 & 73.3 & 6.7 & 26.7 & 93.33 \\
\hline Pseudomonas aeruginosa & 3 & 66.7 & 33.3 & 66.8 & 33.3 & 33.3 & 0 & 33.3 & 33.3 & 0 & 33.3 & 100.0 \\
\hline Enterobacter spp & 7 & 42.9 & 57.1 & 42.9 & 42.9 & 42.9 & 28.6 & 42.9 & 71.4 & 0 & 42.9 & 85.7 \\
\hline Gram positive bacteria & & NB & CIP & $\mathbf{G N}$ & OF & CD & $\mathbf{E}$ & CT & AP & CE & $\mathbf{L V}$ & IMP \\
\hline Staphylococcus aureus & 5 & 0 & 20.0 & 0 & 20.0 & 60.0 & 20.0 & 0 & 0 & 0 & 60.0 & 100.0 \\
\hline Enterococcus spp & 3 & 0 & 0 & 0 & 0 & 66.7 & 0 & 0 & 0 & 0 & 33.3 & 100.0 \\
\hline Corynebacterium spp & 1 & 0 & 0 & 0 & 0 & 100.0 & 100.0 & 0 & 0 & 0 & 100.0 & 100.0 \\
\hline
\end{tabular}


The most frequently isolated bacteria pathogens among the diabetic patients in our study were Proteus spp (18.6\%), Klebsiella spp $(16.9 \%)$ and $E$. coli $(15.5 \%)$, which somewhat agrees with the study by Alebiosu et al., (23) in southwest Nigeria, which reported changing pattern of bacteriuria, with Klebsiella spp (42.4\%) and Proteus spp (38.2\%) accounting for the most common cause of bacteriuria among diabetics. However, bacteria isolated from the non-diabetic patients in our study were predominantly E. coli $(30 \%)$ and Proteus spp $(26.3 \%)$, which agrees with the study of Akinnibosun and Iriakpe (24) in Benin City, Nigeria which reported E. coli $(44.4 \%)$ as the predominant bacteria followed by Proteus mirabilis (22.2\%).

Among the diabetics, gentamicin, ofloxacin, imipenem and ceftriaxone were the most active antibiotics against Gram-positive and Gram-negative bacteria. Generally, resistance to cefuroxime, chloramphenicol, nitrofurantoin, norfloxacin, cefixime, and amoxicillin was high. Among the non-diabetics, imipenem was the most active antibiotics against both Gram positive and Gram-negative bacteria while resistance to norfloxacin, gentamicin, ceftriaxone, ampicillin/cloxacillin, cefixime, and cefuroxime was high. These patterns are similar to those reported by Gangoue et al., (25) in Yaounde, central Cameroon where all Gram-negative isolates were resistant to amoxicillin, with high susceptibility to ofloxacin and imipenem. The high resistance rates reported in our study also agrees with the findings of Tula et al., (26) and Khoshbakht et al., (27).

The high antimicrobial resistance (AMR) rates reported among bacterial pathogens in developing countries often result from overuse and misuse of antibiotics as a result of poor antibiotic prescribing practices by healthcare workers, and self-medication by patients and the general populace. AMR has become a public health challenge around the globe for the last few decades (28). The development of AMR in bacteria population is caused by swift evolution of bacteria genome under selective antibiotic pressure (29), and resistant mutants usually survive in environment such as hospitals where several antimicrobials are usually prescribed and infection prevention and control practices may be suboptimal. Therefore, proper use of antibiotics, especially among the vulnerable populations such as the diabetics, is highly desirable.

\section{Conclusion:}

Although the overall frequency of isolation of bacterial pathogens in the two study populations was not significantly different, female population had a higher pathogen isolation rate than the male population, and diabetic females had a higher frequency of polymicrobial infections compared to non-diabetic female and the male population. The high antimicrobial resistance of the isolated bacteria pathogens underscores the need for clinical microbiology laboratory testings to optimize the management of UTI in diabetic patients.

\section{References:}

1. Rubin, R. H., Shapiro, E. D., Andriole, V. T., Davis, R J., and Stamm, W. E. Evaluation of new antiinfective drugs for the treatment of urinary tract infection. Infectious diseases society of America and the food and drug administration. Clin Infect Dis. 1992; 15 (1): 216 - 227.

2. Saleem, M., and Daniel, B. Prevalence of urinary tract infection among patients with diabetes in Bangalore City. Intern J Emerg Sci. 2011; 1 (2): 133 - 142 .

3. Adeyeba, O. A., Adesiji, Y. O., and Omosigho, P. O. Bacterial urinary tract infections in patients with diabetes mellitus. Intern J Trop Med. 2017; 2: 89 $-92$.

4. Thomas, A. A., Lane, B. R., Thomas, A. Z., Remer, E. M., Campbell, S. C., and Shoskes, D. A. Emphysematous cystitis: A review of 135 cases. Brit J Urol Intern. 2007; 100: 17 - 20.

5. Hoffman, W. H., Burek, C. L., Walker, J. L., Fisher, L. E., Khichi, M., and Mellick, L. B. Cytokine response to diabetic ketoacidosis and its treatment. Clin Immunol. 2003; 108:175 - 181.

6. Joshi N., Caputo, G. M., Weitckamp, M. R., and Karchmer, M. W. Infection in patients with diabetes mellitus. New Eng J Med. 1999; 341: 1906 - 1912.

7. National Institute of Health: The National Kidney and Urologic Diseases Advisory Board. Long Range Plan-window on $21^{\text {st }}$ Century Publication. 1999; 99: $583-590$.

8. Hirji, I., Guo, Z., Anderson, S. W., Hammar, N., and Caminero, A. G. Infection among patients with type 2 diabetes in the United Kingdom general practice and research database (GPRD). J Diab Compl. 2012; 26: 513 - 516

9. $\quad \mathrm{Fu}, \mathrm{A}$. Z., Iglay, K., Qiu, Y., Engel, S., Shanker, R., and Brodovic, Z. K. Risk characterization for urinary tract infections in subjects with newly diagnostic type 2 diabetes. J Diab Compl. 2014; 28 (6): $805-810$

10. Yu, S., Fu, Z., Qiu, Y., et al. Disease burden urinary tract infections among type 2 diabetes mellitus patients in the United States. J Diab Compl. 2014; 28 (5): $621-626$.

11. Nitzan, O., Elias, M., Chazan, B., and Saliba, W. Urinary tract infection in patients with type 2 diabetes mellitus. Review of Prevalence, diagnosis, and management. Diabetes metabolic syndrome 
and obesity: Target and Therapy. 2015; 8: 129 136.

12. Geerling, S. E., Stolk, R. P., and Camp, M. J. Asymptomatic bacteriuria can be considered a diabetic complication in with diabetes mellitus. Adv Exper Med Biol. 2000; 485: 309 - 314

13. Simon-Oke, I. A., Odeyemi, O., and Afolabi, O. J. Incidence of urinary tract infections and antimicrobial susceptibility pattern among pregnant women in Akure, Nigeria. Sci Afr. 2019; 6: 1 - 151.

14 Kama, C., Obeagu, E. I., Alo, M. N., et al. Incidence of Urinary Tract Infection among Diabetic Patients in Abakaliki Metropolis. J Pharm Res Intern. 2020; 32(28): 117-121.

15. Okechukwu, A. A., and Thairu, Y. Bacteria urinary tract infection in HIV-infected children and adolescents in Abuja, Nigeria: a cross-sectional study. Afr J Clin Exper Microbiol. 2019; 20 (4): 306-314.

16. Oluwafemi, T. T., Akinbodewa, A. A., Ogunleye, A., and Adejumo, O. A. Urinary tract infections and antibiotic sensitivity pattern of uropathogens in a tertiary hospital in South West, Nigeria. Sahel Med J. $2018 ; 21: 18-22$.

17. Cheesbrough, M. District laboratory practice in tropical countries (Part II). Cambridge University Press, United Kingdom. 2010; 63-70

18. Clinical and Laboratory Standards Institute (CLSI). Performance standards for antimicrobial susceptibility testing. 28th ed. Supplemental M100. Clinical and Laboratory Standard Institute, Wayne, PA 2018.

19. Kline, K. A., and Lewis, A. L. Gram positive uropathogens, polymicrobial urinary tract infection, and the emerging microbiota of the urinary tract. Microbiol Spectr. 2016; 4 (2): doi: 10.1128/ microbiolspec.UTI-0012-2012

20. Laudisio, A., Marinosci, F., Fontana, D., et al. The burden of comorbidity is associated with symptomatic polymicrobial urinary tract infection among institutionalized elderly. Aging Clin Exp Res. $2015 ; 27(6): 805-812$
21. Pargavi, B., Mekala, T., Thamarai, S. A., and Moorthy, K. Prevalence of urinary tract infections (UTI) among diabetic patients in Vandavasi, Tamil Nadu, India. Intern J Biol Technol. 2011; 2 (2): 42 -45 .

22. Otajevwo, F. D. Urinary tract infection among symptomatic outpatients visiting a tertiary Hospital based in Midwestern Nigeria. Glob J HIth Sci. 2013; 5: 187 - 199

23. Alebiosu, C. O., Osinupebi, O. A., and Olajubu, F. A. Significant asymptomatic bacteriuria among Nigeria type 2 diabetics. J Nat Med Assoc. 2003; 95: 344-351.

24. Akinnibosun, F. I., and Iriakpe, H. J. Prevalence of uropathogens in Diabetic patients and their antimicrobial susceptibility pattern. Nig J Microbiol. 2016; 30 (1): 3235-3240.

25. Gangoue, P. J., Koulla, S. S., Ngassam, P., Adnogo, D., and Ndumbe. P. Antimicrobial activity against Gram negative bacilli from Yaounde central hospital, Cameroon. Afr HIth Sci. 2006; 6 (4): 232-235.

26. Tula, M. Y., and Iyoha, O. Distribution and Antibiotic susceptibility pattern of Bacterial Pathogens causing urinary Tract Infection in Mubi General Hospital, Yola-Nigeria. Br J Med Med Res. 2014; 4 (19): 359 - 360.

27. Khoshbakht, R., Salima, A., Shirzad, A. H., and Keshavarzi, H. Antibiotic Susceptibility of Bacterial Strains Isolated from Urinary Tract Infections in Karaj, Iran. Jundishapur J Microbiol. 2013; 6 (1): 86 -90. doi: $10.5812 /$ jjm.4830

28. Jones, R. N., Baquero, F., Privitera, G., Inoue, M., and Wiedemann, B. Inducible B-lactamase mediated resistance to third-generation cephalosporins. Clin Microbiol Infect. 1997; 3: 7 20.

29. Milan, K., Karel, U., and Tomas, L. Antibiotics selective pressure and development of bacterial resistance. Int J Antimicrob Agents. 2001; 17: 357 -363 . 